DOI: $10.2478 / \mathrm{v} 10025-007-0011-9$

JOURNAL OF WATER

AND LAND DEVELOPMENT

J. Water Land Dev. No. 10, 2006: 133-149

\title{
Evaluation and prediction of silting in reservoir Cedzyna on the Lubrzanka River
}

\author{
Jarosław BODULSKI, Jarosław GÓRSKI
}

Politechnika Świętokrzyska, Katedra Inżynierii Wodnej, al. 1000-lecia Państwa Polskiego 7, 23-314 Kielce, Polska, e-mail: bodulski@tu.kielce.pl

\begin{abstract}
Changes in capacity of water reservoir Cedzyna during its exploitation since 1972 till 2003 are presented in the paper. Analyses were based on cross sections of the reservoir's basin from before its fulfillment (1967) and those measured with the echo sounder Ceeducer in 2003. Silting of reservoir was predicted based on empirical methods. The volume of reservoir was found to decrease by 112.8 thousand $\mathrm{m}^{3}$ during 31 years of its exploitation and reservoir's life span was assessed at 685 years. An error analysis was additionally made of calculating the surface area of a cross section at varying number of sounding sites. It was found that there was no need to note too many coordinates and depths and for the Cedzyna reservoir the distance between measurement sites up to $16 \mathrm{~m}$ was sufficient.
\end{abstract}

Key words: forecast, silting, water reservoir, reservoir capacity

\section{INTRODUCTION}

Water storage is the main function of retention reservoir irrespective of its type and size. The reservoir's life span depends on the amount of inflowing river debris, on the type of reservoir and its location, the size of flood control reserves, on water management and reservoir's capacity. Silting rate varies in time and depends on hydrologic, geo-morphologic and exploitation factors (DĄBKOWSKI, 1974). Hydrologic regime of the catchment basin determines the amount of inflowing water and river debris and their temporal distribution. Sedimentation (amount and place of deposition) in a reservoir is affected by the interacting hydrologic and exploitation factors. Other processes worth mentioning here are: destruction of islands, overgrowing of shallow waters and scroll ridges by vegetation, changes in the chemical composition of water, coagulation of suspended matter, glacial phenomena, long-shore currents etc.

This paper was aimed at estimating present capacity of retention reservoir Cedzyna on the Lubrzanka River and evaluating its future duration. A decrease of 
reservoir's volume due to particle sedimentation for 31 years of its exploitation was analysed. Calculations were based on double measurements of the basin - before the construction in 1967 and in 2003. With available empirical methods a forecast of reservoir's siltation was then elaborated.

\section{CHARACTERISTICS OF THE OBJECT AND STUDY AREA}

The reservoir was built in the years 1967-1972. The dam was situated in 13.4 $\mathrm{km}$ of the Lubrzanka course and backwater at NPP (Normal Water Level) reaches $17.2 \mathrm{~km}$ of the river course. The reservoir is situated near Kielce agglomeration in Podkielecki Area of Protected Landscape (Fig. 1). At present reservoir is administered by Świętokrzyski Board of Land Reclamation and Water Facilities in Kielce. The reservoir is not used in flood control; it was mainly constructed for agricultural purposes (levelling of discharge in the vegetation period) and for recreation

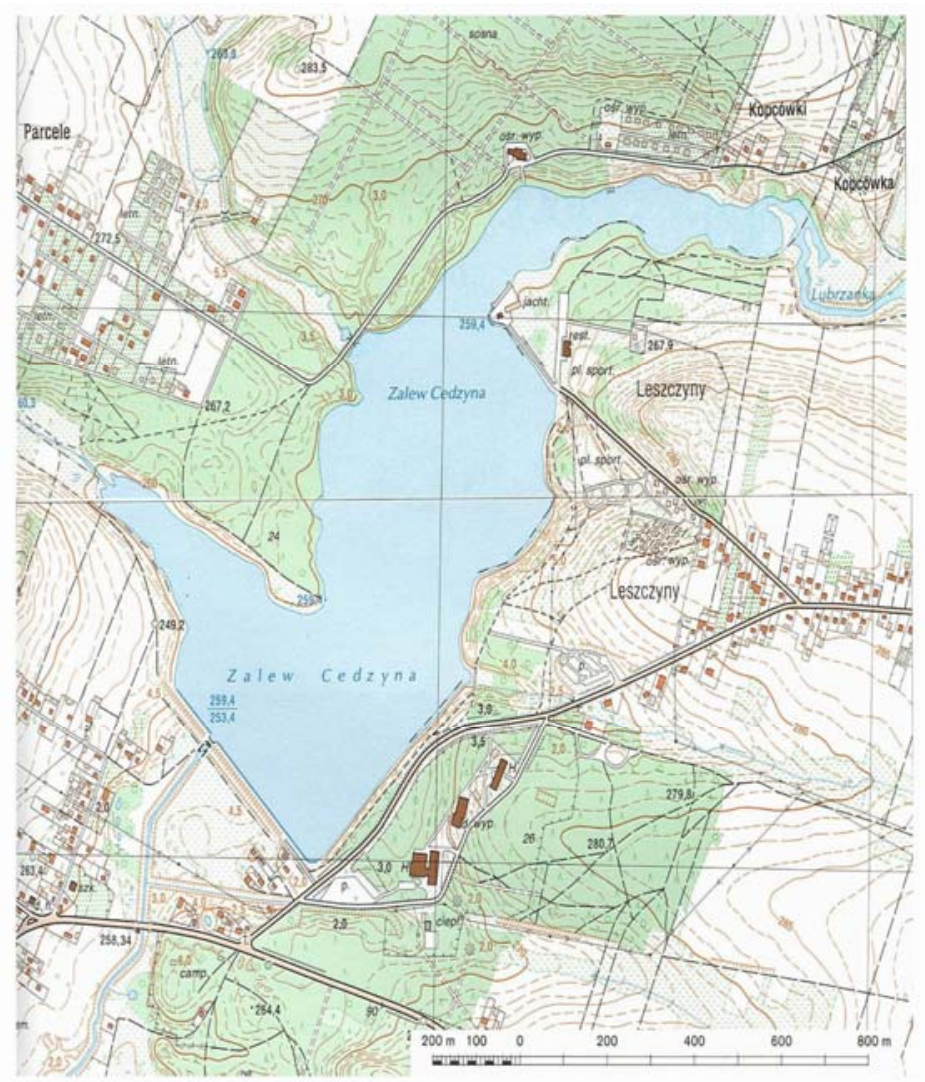

Fig. 1. A sketch of the reservoir 
of inhabitants from Kielce and surrounding. The weir has a reinforced concrete, two-spanned $(2 \times 5.0 \mathrm{~m})$ step $1.2 \mathrm{~m}$ high with two releases of $\phi=0.6 \mathrm{~m}$ situated near abutments. In the years 1998-2000 the reservoir was rebuilt by compacting the body of a dam and adding anti-filtration membrane. Surface area of reservoir for standard water lifting ( $260 \mathrm{~m}$ a.s.1.) is 64 ha and capacity -1.55 million $\mathrm{m}^{3}$. Under such conditions mean depth is $2.5 \mathrm{~m}$. For extreme situations pertaining to water flow $Q_{1 \%}=162 \mathrm{~m}^{3} \cdot \mathrm{s}^{-1}$ and water table ordinate $262.12 \mathrm{~m}$ a.s.l. reservoir's capacity is 3.2 million $\mathrm{m}^{3}$ and its area -84 ha.

Storage curve and fulfilment curve were elaborated in the Kielce Branch of CBSiPWM in 1966 (Fig. 2). Characteristic water stages and flows for water gauge "Cedzyna" were additionally prepared based on data from the State Institute of Hydrology and Meteorology for selected average year (1951) out of the 22 years long (1944-1966) observation series (Table 1).

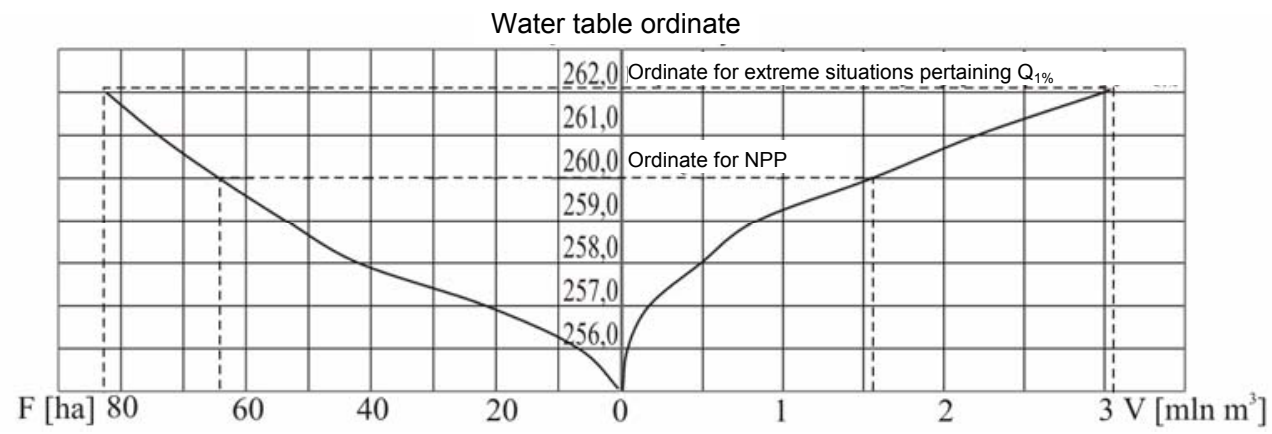

Fig. 2. Storage curve and fulfilment curve of reservoir Cedzyna

Table 1. Characteristic water stages and flows in the Lubrzanka at water gauge cross section Cedzyna (CHAIŃSKI, 2000).

\begin{tabular}{l|l|l|r}
\hline \multicolumn{1}{c}{ Characteristic stages } & $\begin{array}{c}H \\
\mathrm{~cm}\end{array}$ & \multicolumn{1}{c}{ Characteristic flows } & $\begin{array}{c}Q \\
\mathrm{~m}^{3} \cdot \mathrm{s}^{-1}\end{array}$ \\
\hline WWW - the highest of highest & 450 & WWQ - the highest of highest & 122.00 \\
SWW - mean of highest & 341 & SWQ - mean of highest & 56.70 \\
SW - mean & 167 & SQ - mean & 0.45 \\
SNW - mean of lowest & 146 & SNQ - mean of lowest & 0.13 \\
NNW - the lowest of lowest & 137 & NNQ - the lowest of lowest & 0.07 \\
ZW - standard (180 days) & 159 & ZQ - standard (180 days $)$ & 0.37 \\
\hline
\end{tabular}

According to geographic division of Poland (KONDRACKI, 2000; TRAMPLER, 1990) the Lubrzanka catchment basin down to the dam of reservoir Cedzyna is 
situated in mesoregion of the Świętokrzyskie Mts which belongs to macroregion Kielce Plain - part of sub-province Małopolska Plain. The highest peak of the Świętokrzyskie Mts - Łysica (altitude $611.8 \mathrm{~m}$ a.s.1.) is also the highest elevation of the catchment.

In spite of relatively low altitude of the mesoregion its climatic conditions are more severe than those of surrounding lowlands. Mean air temperature is by $1-2^{\circ} \mathrm{C}$ lower, precipitation is higher and exceeds $600 \mathrm{~mm}$ annually. Icy phenomena usually appear between 10th and 20th of December and end between February 28th and March 10th in south-eastern part of the mesoregion and between 10th and 20th of March elsewhere. Mean duration of ice cover is 20 to 40 days (SIDEE, 2005). Pine tree stands can be found in lower parts, upper parts and slopes are dominated by fir and beech forests. Larch and yew are locally present.

Upper part of the Lubrzanka catchment is of upland character and its basic characteristics is given in Table 2. Catchment's shape resembles flattened circle. Its surface area down to the Cedzyna water gauge situated under bridge on the road Kielce - Łagów is $140.7 \mathrm{~km}^{2}$. River length from springs to the gauge is $L=21.6$ $\mathrm{km}$. Sixty two percent of the catchment is occupied by arable lands, the rest $32.4 \%$ is covered by forests and grasslands. The river springs from Trias sandstones near Zagnańsk at $360 \mathrm{~m}$ a.s.l. It flows in a valley between Bukowa Góra and the Masłowski crest filled with Trias and Sylur sandstones covered by Quaternary formations. Apart from the Lubrzanka two other streams: the Zajączkowa Struga (catchment basin of $11.6 \mathrm{~km}^{2}$ ) and an unnamed stream (catchment basin of 10.9 $\mathrm{km}^{2}$ ) enter the reservoir

Table 2. Physical and geographic parameters and the types of land use in the Lubrzanka catchment basin down to "Cedzyna" profile

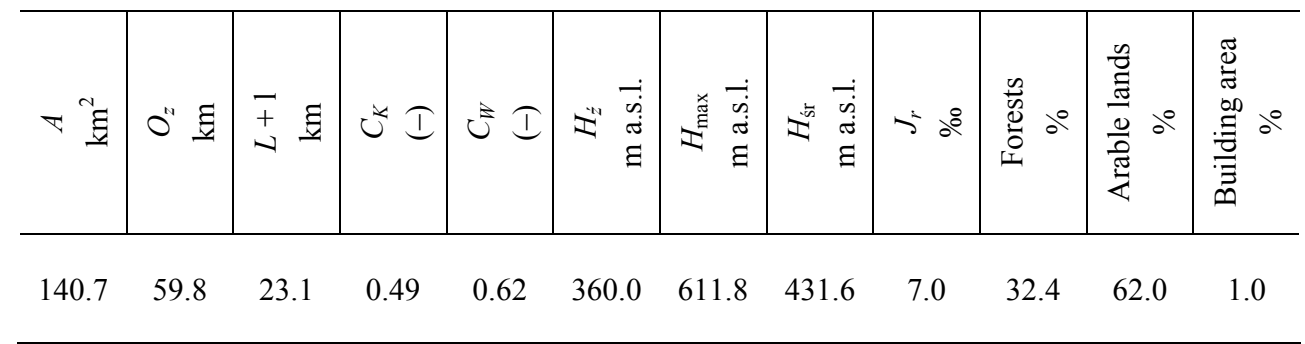

$A$ - surface area of the catchment down to Cedzyna, $O_{z}$ - circumference, $L+1$ - length of the main stream $(L)$ to Cedzyna water gauge with dry valley (1) to watershed, $C_{K}=4 \pi A / O_{z}^{2}$ - roundness index of the catchment, $C_{W}=$ $2 / L(A / \pi)^{1 / 2}$ - elongation index, $H_{\dot{z}}$ - altitude of springs, $H_{\max }$ - the highest point in the catchment, $H_{\text {sr }}-$ mean altitude of the catchment area, $J_{r}=\left(W_{g}-W_{d}\right) /(L+1)$ - slope of the river, for $W_{g}$-altitude on watershed in the prolongation of dry river valley, $W_{d}$-altitude of water gauge profile. 


\section{METHODS AND RESULTS}

\section{ELABORATION OF THE INPUT DATA}

Capacity of retention reservoir "Cedzyna" was calculated based on cross sections measured before dam construction and on sounding of reservoir's bottom on 1 st and 2nd September 2003 at the water table altitude of $259.73 \mathrm{~m}$ a.s.1. Measurements were made with the echo-sounder Ceeducer Hydrographic Survey System ${ }^{1)}$ of depth measuring range between 0.3 and $99.99 \mathrm{~m}$ and an accuracy of $0.01 \mathrm{~m}$ or $0.02 \%$. Echo-sounder was equipped with 8-channel satellite receiver GPS that enabled estimating geographic coordinates to the nearest $2-3 \mathrm{~m}$. Depth and geographic location were measured every two seconds. At moving velocity of c. 0.8 $\mathrm{m} \cdot \mathrm{s}^{-1}$ there were 245 measured points along one cross section on average and the widest sections near the dam were characterised by even 350 points. Results (geographic coordinates and depths of every point) were stored in an internal $10 \mathrm{MB}$ memory that allowed for 7 hours continuous recording. Forty two cross sections and coordinates of the dam's axis were measured (Fig. 3). Additionally, longitudinal profiles were measured when returning to the harbour. In total, measurements

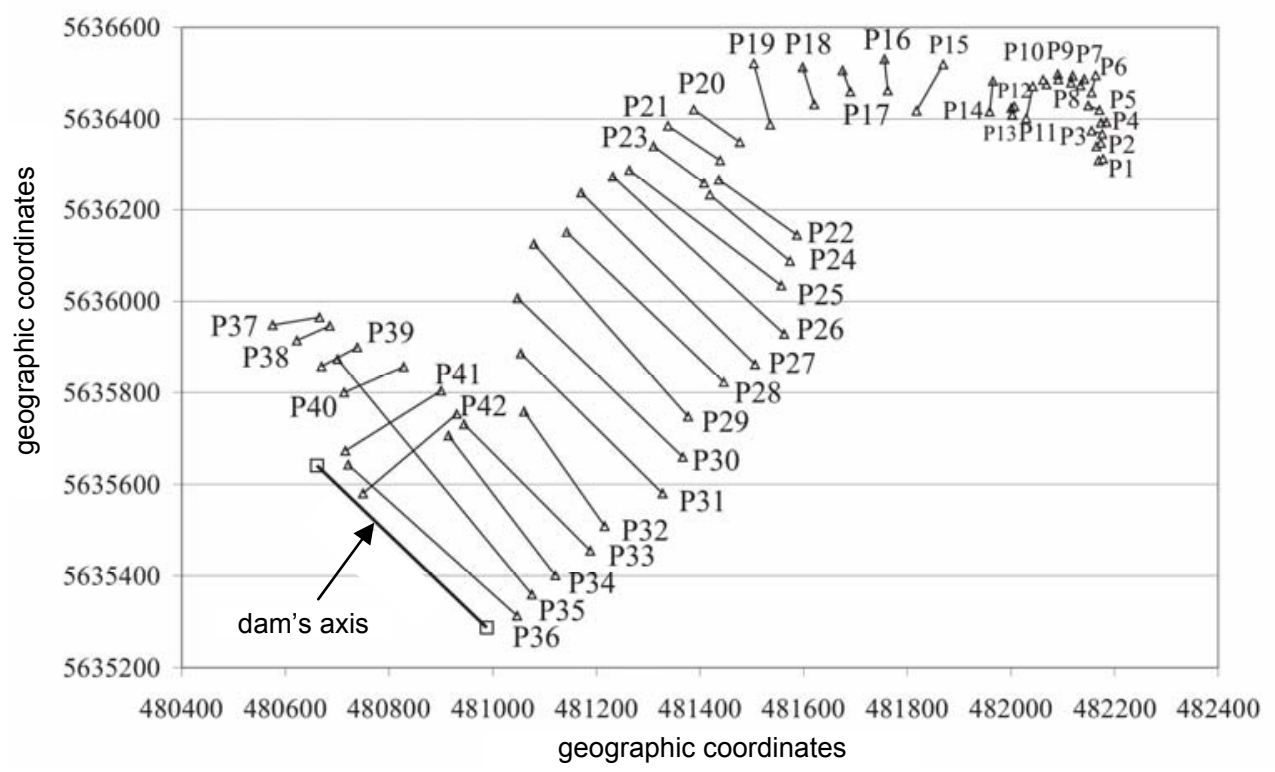

Fig. 3. Distribution of cross sections after sounding in geographic coordinate system "geographic coordinates"

\footnotetext{
1) Sounding was supervised by Dr eng. Z. Popek, Department of Water Engineering, Warsaw Agricultural University.
} 
were made in c. 10300 points and results were stored in 60 datasets. Measured cross sections were spanned by $76 \mathrm{~m}$ on average.

Shapes and distribution of selected cross sections are presented in Fig. 4. The sections had the same depth with one depression in place of a former river channel. Deepest places were found near the left bank of reservoir. Solid line in Fig. 5 presenting mean depths in cross sections after sounding is clearly above dashed line drawn for mean depths in primary cross sections. Differences between the two represent the depth of sediments. As could be seen, the differences are greatest near dam and in backwater of reservoir.

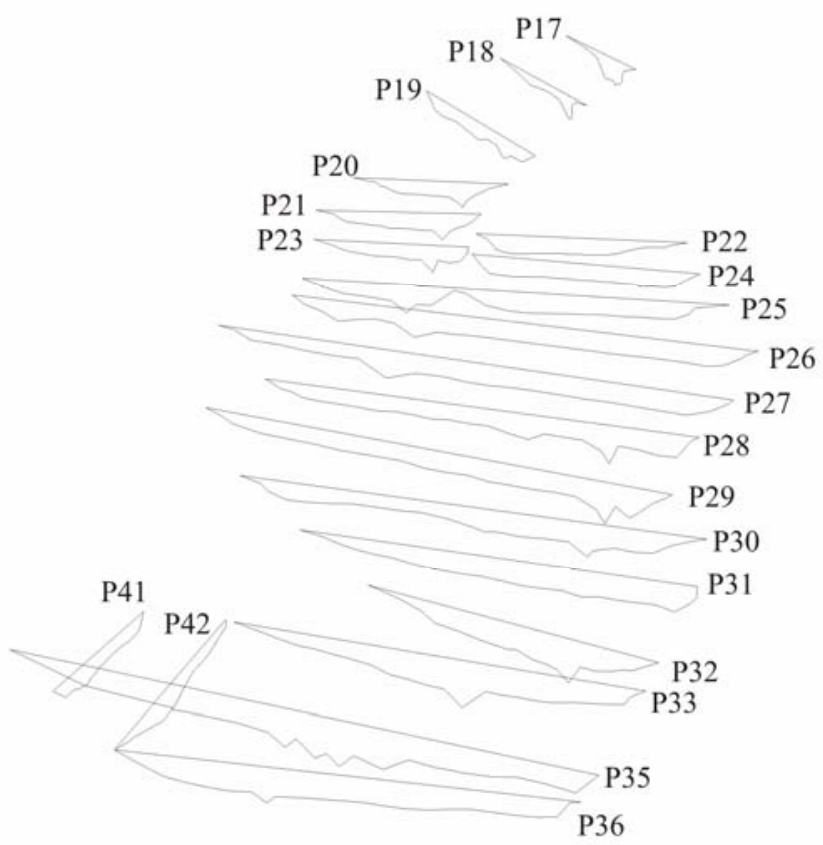

Fig. 4. Distribution and shape of selected cross sections made with the Ceeducer echo sounder in 2003

Due to voluminous dataset from soundings an analysis was performed of the error in calculating the cross section area for altered number of sounding points. Analysis was made for five randomly selected cross sections numbered: 20, 24, 28, 34, 36. Table 3 presents the number of sampling points in selected cross sections and percentage differences in areas related to the altered number of sounded points. Due to small $( \pm 2 \%)$ differences in calculated surface area, in comparison with the error of $\pm(3-11) \%$ common in practise (DABBKOWSKI, 1989), it was decided to reduce the number of records used in further analysis. Cross sections obtained from soundings carried out every 20 seconds were adopted. 


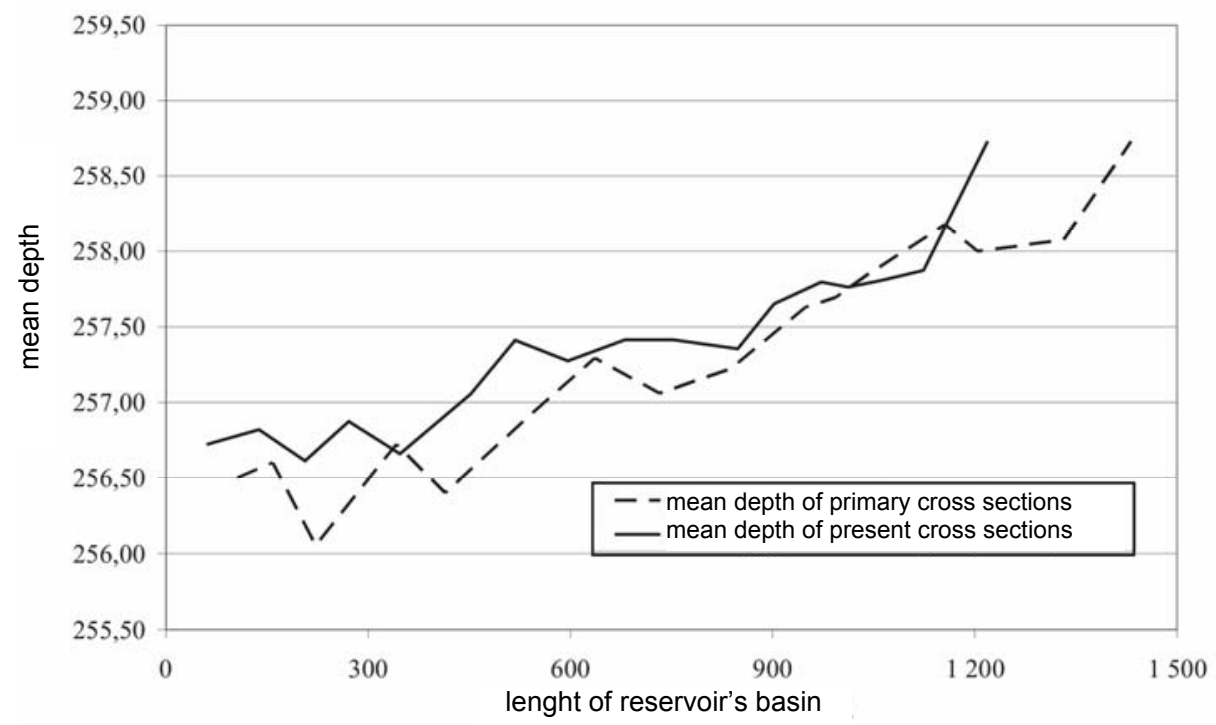

Fig. 5. Distribution of mean depths along reservoir

Data presented in Table 3 show that there was no need to record depth and coordinates from too many sampling points. In the analysed case an average distance between these points could have been up to $16 \mathrm{~m}$.

\section{DETERMINATION OF RESERVOIR'S CAPACITY FROM MEASUREMENTS}

Due to local conditions, bad weather on sampling days (strong wind and high waves), immersion of boat to c. $20 \mathrm{~cm}$, difficulties in keeping the course, overgrown shallows, sounding to the very shoreline was not possible. Additionally, sounding had to be finished some distance from the shore to avoid interferences of the GPS signal and resulting errors in estimating position from high trees bent over water. Therefore, end points of cross sections were usually situated $5 \mathrm{~m}$ (sometimes $10 \mathrm{~m}$ ) from the shoreline.

For reasons mentioned above, a lower water table than that on the day of sounding was adopted to calculate differences in reservoir's volume during its exploitation. Adopted altitude was $258.73 \mathrm{~m}$ a.s.l. This choice assured the greatest number of cross sections whose end altitudes were above or equal to the water table altitude. All cross sections that fulfilled this condition and were situated between the dam axis and the cross section whose bottom altitude was higher than adopted water table were selected for further analysis. Sixteen cross sections made in 1967 and 18 sounded in September 2003 were qualified (Table 4). 
Table 3. Errors $\sigma_{F}$ of estimating cross section area $F$ at altered number of measured points $n$ for water table altitude equal to $259.73 \mathrm{~m}$ a.s.1.

\begin{tabular}{|c|c|c|c|c|c|c|c|c|c|c|c|c|c|c|c|c|c|c|}
\hline \multirow{2}{*}{ 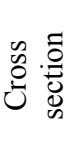 } & \multicolumn{18}{|c|}{ Number of points, respective values of $F$ and errors $\sigma_{F}$} \\
\hline & $\begin{array}{l}n \\
-\end{array}$ & $\begin{array}{c}F \\
\mathrm{~m}^{2}\end{array}$ & $\begin{array}{l}\sigma_{F} \\
\%\end{array}$ & $\begin{array}{l}n \\
-\end{array}$ & $\begin{array}{c}F \\
\mathrm{~m}^{2}\end{array}$ & $\begin{array}{l}\sigma_{F} \\
\%\end{array}$ & $\begin{array}{l}n \\
-\end{array}$ & $\begin{array}{c}F \\
\mathrm{~m}^{2}\end{array}$ & $\begin{array}{l}\sigma_{F} \\
\%\end{array}$ & $\begin{array}{l}n \\
-\end{array}$ & $\begin{array}{c}F \\
\mathrm{~m}^{2}\end{array}$ & $\begin{array}{l}\sigma_{F} \\
\%\end{array}$ & $\begin{array}{l}n \\
-\end{array}$ & $\begin{array}{c}F \\
\mathrm{~m}^{2}\end{array}$ & $\begin{array}{l}\sigma_{F} \\
\%\end{array}$ & $\begin{array}{l}n \\
-\end{array}$ & $\begin{array}{c}F \\
\mathrm{~m}^{2}\end{array}$ & $\begin{array}{l}\sigma_{F} \\
\%\end{array}$ \\
\hline 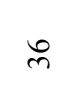 & $\overrightarrow{\mathrm{\sigma}}$ & $\stackrel{+}{\dot{\sigma}}$ & 0 & $\bar{m}$ & 官 & $\stackrel{0}{\stackrel{0}{0}}$ & $\hat{\infty}$ & $\begin{array}{l}\infty \\
\dot{8} \\
\dot{8}\end{array}$ & $\stackrel{+}{0}$ & $\ddot{6}$ & $\begin{array}{l}0 \\
\infty \\
\infty \\
\text { లે }\end{array}$ & $\stackrel{⿱ 亠 士}{0}$ & กิ & ָे & $\stackrel{n}{0}$ & ำ & $\begin{array}{l}\infty \\
\dot{0} \\
\infty \\
=\end{array}$ & $\stackrel{\Xi}{\Xi}$ \\
\hline m & $\vec{\vartheta}$ & 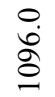 & 0 & $\stackrel{6}{=}$ & $\begin{array}{l}\text { t. } \\
\text { } \\
\stackrel{0}{0}\end{array}$ & $\stackrel{n}{0}$ & 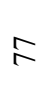 & $\begin{array}{l}\text { t. } \\
\text { }\end{array}$ & $\begin{array}{l}\text { to } \\
\dot{0}\end{array}$ & in & $\begin{array}{l}\text { ఫें } \\
\text { ᄋे }\end{array}$ & $\stackrel{\infty}{\stackrel{\infty}{0}}$ & $\stackrel{\circ}{+}$ & $\stackrel{g}{\dot{g}}$ & $\frac{0}{0}$ & $\ddot{\sim}$ & $\begin{array}{l}\hat{0} \\
\dot{\infty}\end{array}$ & ڤั \\
\hline$\stackrel{\sim}{\sim}$ & m & $\stackrel{0}{\stackrel{0}{0}}$ & 0 & $\underline{6}$ & $\begin{array}{l}n \\
\stackrel{0}{0} \\
\stackrel{0}{0}\end{array}$ & $\stackrel{2}{0}$ & $\stackrel{0}{=}$ & $\begin{array}{l}\infty \\
\dot{0} \\
0\end{array}$ & $\stackrel{\infty}{\stackrel{0}{0}}$ & $\infty$ & $\begin{array}{l}0 \\
\stackrel{0}{0} \\
0\end{array}$ & $\stackrel{n}{0}$ & 8 & $\begin{array}{l}n \\
\text { ปे }\end{array}$ & $\frac{ \pm}{0}$ & $m$ & ڤั่ & $\stackrel{ \pm}{0}$ \\
\hline$\stackrel{\sim}{\sim}$ & 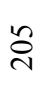 & $\begin{array}{l}n \\
n \\
n \\
y\end{array}$ & 0 & $\stackrel{n}{0}$ & $\begin{array}{l}0 \\
\dot{n} \\
i \\
y\end{array}$ & $\begin{array}{l}\text { ठ̊. } \\
\stackrel{0}{0}\end{array}$ & 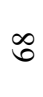 & $\begin{array}{l}0 \\
i n \\
\ddot{f}\end{array}$ & $\stackrel{\overrightarrow{0}}{\dot{\varphi}}$ & $\bar{n}$ & $\begin{array}{l}\stackrel{0}{0} \\
i n \\
\stackrel{+}{+}\end{array}$ & $\exists$ & $\exists$ & $\begin{array}{l}m \\
i n \\
y\end{array}$ & $\stackrel{n}{0}$ & $\vec{\sim}$ & 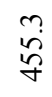 & $\stackrel{n}{o}$ \\
\hline ণิ & $\stackrel{\text { ב }}{ح}$ & iㅗ & 0 & $\widetilde{\sigma}$ & 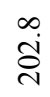 & Õ. & 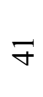 & 옹 & $\hat{n}$ & $\bar{m}$ & $\begin{array}{l}\infty \\
\dot{\vec{\lambda}}\end{array}$ & $\stackrel{n}{\stackrel{n}{0}}$ & 2 & $\begin{array}{l}\infty \\
\text { ¿̊ } \\
\text { in }\end{array}$ & $\stackrel{+}{0}$ & $\simeq$ & $\begin{array}{l}0 \\
\dot{8} \\
\stackrel{0}{0}\end{array}$ & $\hat{\overbrace{}}$ \\
\hline
\end{tabular}


Table 4. Parameters of cross sections for the adopted criterion of water table at $258.73 \mathrm{~m}$ a.s.1.

\begin{tabular}{|c|c|c|c|c|c|c|c|c|}
\hline \multirow[b]{2}{*}{ No. } & \multicolumn{4}{|c|}{ Primary cross sections (1967) } & \multicolumn{4}{|c|}{ Sounded cross sections (2003) } \\
\hline & \begin{tabular}{|c|} 
Numbers \\
of cross \\
sections \\
from the \\
dam's axis
\end{tabular} & $\begin{array}{c}F \\
\mathrm{~m}^{2}\end{array}$ & $\begin{array}{l}B \\
\mathrm{~m}\end{array}$ & $\begin{array}{c}H_{\mathrm{sr}}=F / B \\
\mathrm{~m}\end{array}$ & $\begin{array}{c}\text { Numbers } \\
\text { of cross } \\
\text { sections } \\
\text { from the } \\
\text { dam's axis }\end{array}$ & $\begin{array}{c}F \\
\mathrm{~m}^{2}\end{array}$ & $\begin{array}{l}B \\
\mathrm{~m}\end{array}$ & $\begin{array}{c}H_{\text {sr }}=F / B \\
\mathrm{~m}\end{array}$ \\
\hline 1 & 2 & 1029.90 & 461.70 & 2.23 & 36 & 934.34 & 464.88 & 2.01 \\
\hline 2 & 3 & 1585.57 & 744.00 & 2.13 & 35 & 1300.79 & 680.70 & 1.91 \\
\hline 3 & 4 & 1166.61 & 436.10 & 2.68 & 34 & 781.09 & 368.94 & 2.12 \\
\hline 4 & 5 & 648.52 & 323.00 & 2.01 & 33 & 636.19 & 342.70 & 1.86 \\
\hline 5 & 6 & 678.74 & 291.40 & 2.33 & 32 & 588.81 & 284.30 & 2.07 \\
\hline 6 & 7 & 556.79 & 305.40 & 1.82 & 31 & 660.73 & 394.60 & 1.67 \\
\hline 7 & 8 & 542.88 & 377.70 & 1.44 & 30 & 604.64 & 458.10 & 1.32 \\
\hline 8 & 9 & 847.21 & 507.60 & 1.67 & 29 & 714.84 & 491.30 & 1.45 \\
\hline 9 & 10 & 762.05 & 505.40 & 1.51 & 28 & 591.95 & 449.57 & 1.32 \\
\hline 10 & 11 & 449.59 & 406.60 & 1.11 & 27 & 691.35 & 524.90 & 1.32 \\
\hline 11 & 12 & 440.86 & 425.50 & 1.04 & 26 & 653.86 & 475.10 & 1.38 \\
\hline 12 & 13 & 284.11 & 323.30 & 0.88 & 25 & 416.68 & 386.40 & 1.08 \\
\hline 13 & 14 & 67.83 & 122.30 & 0.55 & 24 & 236.16 & 220.43 & 1.07 \\
\hline 14 & $14 \mathrm{a}$ & 79.71 & 109.30 & 0.73 & 23 & 106.79 & 132.30 & 0.81 \\
\hline 15 & 15 & 113.78 & 173.50 & 0.66 & 22 & 147.49 & 152.30 & 0.97 \\
\hline 16 & 16 & 0.00 & 0.00 & 0.00 & 21 & 125.56 & 136.30 & 0.92 \\
\hline 17 & & & & & 20 & 87.61 & 102.20 & 0.86 \\
\hline 18 & & & & & 19 & 0.00 & 0.00 & 0.00 \\
\hline
\end{tabular}

$F$ - surface area. $B$ - width of the cross section. $H_{\text {sr }}$ - mean depth in a cross section.

According to bottom topography in 1967 and based on the results of sounding in 2003 cross section surface areas and distances between neighbouring cross sections were calculated. Reservoir's volume was calculated by multiplying mean surface areas of the cross sections and distances between them. Calculated volume for 16 cross sections from 1967 and for adopted water table at $258.73 \mathrm{~m}$ a.s.l. was 796.4 thousand $\mathrm{m}^{3}$ and agreed with the volume from capacity curve (Fig. 2). For 18 cross sections sounded with the Ceeducer echo sounder in 2003 and at the same water table elevation the volume was 683.5 thousand $\mathrm{m}^{3}$. The difference calculated for 31 years of exploitation was thus 112.8 thousand $\mathrm{m}^{3}$. Mean annual loss of capacity calculated for that period was 3.64 thousand $\mathrm{m}^{3} \mathrm{y}^{-1}$.

According to LAJCZAK (1995) the amount of material settled in reservoirs, equal to capacity loss, calculated from sounding data is similar or even twice that obtained from transported mass balance. 
ESTIMATION OF THE MEAN ANNUAL AMOUNT OF RIVER DEBRIS DELIVERED TO RESERVOIR

Basic requirement to evaluate the silting of reservoir is to estimate the mass of delivered river debris divided into bed load and suspended load. Most reliable method is to make direct measurements in a river in properly selected cross sections. When direct measurements are not available, the mass of river debris is estimated with empirical methods.

Estimation of the denudation in a catchment. Mean annual mass of the products of denudation can be estimated upon the classification of soil erosion processes given by RENIGER (1959) and quantitative indices of denudation established by DĘBSKI (1959) using the equation:

$$
D=\sum_{1}^{n} F_{i} I_{i}
$$

where:

$D$ - mean annual mass of denudation products, $\mathrm{t} \cdot \mathrm{y}^{-1}$;

$F_{i}$ - part of the catchment area respective to a given denudation class, $\mathrm{km}^{2}$;

$I_{i}$ - intensity of denudation in a given class, $\mathrm{t} \cdot \mathrm{km}^{-2} \cdot \mathrm{y}^{-1}$.

Most of the Cedzyna reservoir catchment basin (76\%) falls in the last, ninths class of this classification. The intensity of denudation in this class is $417 \mathrm{t} \cdot \mathrm{km}^{-2} \cdot \mathrm{y}^{-1}$. Rest of the catchment (24\%) near Kielce is in the 4th class whose respective intensity is $28.8 \mathrm{t} \cdot \mathrm{km}^{-2} \cdot \mathrm{y}^{-1}$. Annual mass of denudation products in the catchment of Cedzyna reservoir is thus:

$D=106.9 \mathrm{~km}^{2} \cdot 417 \mathrm{t} \cdot \mathrm{km}^{-2} \cdot \mathrm{y}^{-1}+33.76 \mathrm{~km}^{2} \cdot 28.8 \mathrm{t} \cdot \mathrm{km}^{-2} \cdot \mathrm{y}^{-1}=45.6$ thousand $\mathrm{t} \cdot \mathrm{y}^{-1}$.

Estimation of the mean annual suspended load. Because of lacking data on the amount of suspended matter delivered to reservoir in a year the load was calculated from the index of outflow denudation given by BRAŃSKI (1975):

$$
R=\sum_{i=1}^{n} \alpha_{i} F_{i}
$$

where:

$R$ - mean annual suspended load, $\mathrm{t}$;

$\alpha_{i}$ - denudation index for partial catchment, $\mathrm{t} \cdot \mathrm{km}^{-2}$;

$F_{i}$ - surface area of partial catchment, $\mathrm{km}^{2}$.

The index of outflow denudation was based on measurements in cross sections closing the catchments. The catchment of Cedzyna reservoir is one of partial catchments of the Nida basin for which the index of outflow denudation is 2.83 
$\mathrm{t} \cdot \mathrm{km}^{-2}$. For the Kamienna River neighbouring the Nida basin from the north the index is $45.5 \mathrm{t} \cdot \mathrm{km}^{-2}$, so several times higher. Due to the upland character of the Cedzyna reservoir catchment basin (slope 7\%o), similar to the Kamienna location in mesoregion of the Świętokrzyskie Mts and sources of both rivers in the same mountain ridge, it was decided to adopt the index of outflow denudation equal to $45.5 \mathrm{t} \cdot \mathrm{km}^{-2}$. Suspended load calculated from eq. (2) for this index is $6401.8 \mathrm{t} \cdot \mathrm{y}^{-1}$. To estimate the transport of suspended load a map of average turbidity of Polish rivers elaborated by BRAŃSKI (1968) was additionally used. Because mean annual turbidity for closing profile of Cedzyna reservoir was not available, the value for the Kamienna River in Kunów profile $\left(287 \mathrm{~g} \cdot \mathrm{m}^{-3}\right)$ was adopted as before. Mean annual water discharge of $0.45 \mathrm{~m}^{3} \cdot \mathrm{s}^{-1}$ (mean for the years 1944-1966) was taken from the reservoir's project. Annual suspended load was calculated from the equation:

$$
R=31,536 P_{\dot{s} r} Q_{\dot{s} r}
$$

where:

$R$ - average annual suspended load, $\mathrm{t}$;

$P_{s r}-$ mean turbidity taken from the map, $\mathrm{g} \cdot \mathrm{m}^{-3}$;

$Q_{s r}$ - mean annual water discharge, $\mathrm{m}^{3} \cdot \mathrm{s}^{-1}$.

For adopted mean values of water discharge and turbidity the suspended load is $4072.9 \mathrm{t} \cdot \mathrm{y}^{-1}$ in an average year.

Estimation of the mean annual bed load. Wilhelm's empirical formula used by LAJCZAK (1995) and MICHALEC (2001) for dam reservoirs on mountain rivers in southern Poland was applied to estimate mean annual bed load. The load is expressed as:

$$
\bar{I}=523 \bar{Q} J
$$

where:

$\bar{I}-$ mean annual delivery of bed load to reservoir, $\mathrm{t} \cdot \mathrm{y}^{-1}$

$J$-mean slope of the channel of the main stream, \%o.

$\bar{Q}$ - mean annual discharge in calculation profile, $\mathrm{m}^{3} \cdot \mathrm{s}^{-1}$.

Mean water input to reservoir was calculated from mean flow established in the reservoir's project at $0.45 \mathrm{~m}^{3} \cdot \mathrm{s}^{-1}$. Channel slope was taken as in table 2 . Bed load delivered to reservoir calculated from eq. (4) is thus $1647.4 \mathrm{t} \cdot \mathrm{y}^{-1}$. Additionally, the mass of bed load equal to $35 \%$ of suspended load delivered to reservoir was adopted after SKIBIŃSKI (1976). Similar ratio of bed to suspended load was obtained by BARTNIK (1997) who calculated loads for the Skawa River with the TRANS programme and by RATOMSKI et al. (1997) for Tresna reservoir. With this 
assumption and using eq. (2) one obtains $2240.6 \mathrm{t} \cdot \mathrm{y}^{-1}$ of bed load delivered to reservoir. For suspended load calculated acc. to (3) the bed load is $1425.5 \mathrm{t} \cdot \mathrm{y}^{-1}$.

Compilation of calculated loads delivered to reservoir. Loads delivered to reservoir calculated with each of applied methods are compiled in table 5 . They are expressed in terms of mass and volume. To obtain the latter values the mean density of bed and suspended load of $1.75 \mathrm{t} \cdot \mathrm{m}^{-3}$ and $0.7 \mathrm{t} \cdot \mathrm{m}^{-3}$ was adopted after WIŚNIEWSKI (1969). The values were estimated for mountain and submountain reservoirs.

Table 5. Compilation of loads delivered to Cedzyna reservoir

\begin{tabular}{l|c|r}
\hline \multirow{2}{*}{ Method } & \multicolumn{2}{c}{ Suspended load delivered to reservoir } \\
\cline { 2 - 3 } & $\mathrm{t} \cdot \mathrm{y}^{-1}$ & $\mathrm{~m}^{3} \cdot \mathrm{y}^{-1}$ \\
\hline Acc. to denudation index by Brański (2) & 6401.8 & 9145.4 \\
Acc. to turbidity index by Brański (3) & 4072.9 & 5818.4 \\
& Bed load delivered to reservoir \\
Acc. to Wilhelm's formula (4) & 1647.4 & 941.4 \\
Acc to Skibiński as 35\% of load from eq. (2) & 2240.6 & 1280.3 \\
Acc to Skibiński as 35\% of load from eq. (3) & 1425.5 & 814.6 \\
\hline
\end{tabular}

The amount of suspended matter delivered to Krempna reservoir on the Wisłoka estimated from measured (with a photo-optic device) suspension and water discharge (MICHALEC, 2001) served for evaluating the reliability of results obtained in the present study. Both surface area and slope of the Wisłoka catchment (Krempna profile) are similar to respective values for the Lubrzanka (Cedzyna profile) $\left(F=165.3 \mathrm{~km}^{2}, L=18.6 \mathrm{~km}, I=10 \%\right)$. Mean annual suspended load in the Wisłoka for the years $1972-1998$ was $8386.5 \mathrm{t}^{-1} \mathrm{y}^{-1}$ being higher by c. $23 \%$ than the suspended load in the Lubrzanka calculated from eq. (2) and by c. $51 \%$ than that calculated from eq. (3). Having in mind that the surface area and slope of the Wisłoka catchment basin are larger by $15 \%$ and $30 \%$, respectively, than respective values for the Cedzyna one might conclude that suspended load measured by MICHALEC (2001) does not differ markedly from that calculated with eq. (2) acc. to BRAŃSKI (1975).

\section{PREDICTION OF RESERVOIR SILTATION}

Assessment of reservoir's accumulation capacity. Sediments are a mixture of bed load usually trapped in total within reservoir and part of suspended solids. The amount depends on the accumulation capacity of a reservoir. The accumulation capacity is meant as percent of suspended load settled in a year 
in relation to suspended load delivered by the river. It depends on the ratio of reservoir's volume to annual water input. Using two most frequently recommended equations of Brune and Łopatin and their graphic interpretation (BRAŃSKI and DĄBKOWSKI, 1976) the capacity of Cedzyna reservoir to retain the loads was calculated. According to Brune's equation the capacity was $79 \%$ and according to Łopatin's one $-87 \%$. Mean of the two $(83 \%)$ was adopted as a real value. Considering calculated accumulation capacity the total sedimentation of suspended matter calculated from eq. (2) should not exceed $5313.5 \mathrm{t} \cdot \mathrm{y}^{-1}$ and that acc. to eq. (3) $3380.5 \mathrm{t} \cdot \mathrm{y}^{-1}$.

Compilation of the amount of material trapped in reservoir. Table 6 presents calculated mean amounts of material trapped annually in reservoir separately for suspended and bed loads and for both. Accumulation capacity of reservoir was considered for suspended loads.

Prediction of reservoir siltation with time. As seen from observations carried out in many reservoirs the relationship between time and sediment volume is not linear for a longer period of time. Together with proceeding siltation the load flowing through a reservoir increases. Most suitable for forecasting siltation is practically the equation of GONČAROV (1962):

$$
z_{t}=V_{o}\left[1-\left(1-\frac{z_{1}}{V_{o}}\right)^{t}\right]
$$

where:

$z_{t}$ - sediment volume after $t$ years, $\mathrm{m}^{3}$;

$V_{o}$ - initial reservoir capacity, $\mathrm{m}^{3}$;

$z_{1}-$ siltation during the first year of exploitation, $\mathrm{m}^{3}$;

$t$ - years of reservoir exploitation.

Equation (5) was used to calculate siltation of reservoir Cedzyna. The input data was adopted as $z_{1}$ equal to mean total (suspended and bed) load retained annually in reservoir calculated for every method (Table 6). Initial volume for the NPP altitude $=260.0 \mathrm{~m}$ a.s.1. was $V_{o}=1.55$ million $\mathrm{m}^{3}$. Calculation was performed for 31 years of exploitation and its results are presented in Figure 6. Based on eq. (5) at $z_{1}$ assumed $80 \%$ of total capacity at NPP the practical period of reservoir exploitation was additionally established. The longest life span of 685 years was obtained from sounding data. With other methods the life span ranged from 280 and 440 years. 
Table 6. The amount of sediment trapped in Cedzyna reservoir

\begin{tabular}{|c|c|c|c|c|c|c|}
\hline \multirow{3}{*}{ Method } & \multicolumn{6}{|c|}{ Amount of trapped material } \\
\hline & \multicolumn{2}{|c|}{ total } & \multicolumn{2}{|c|}{ suspension } & \multicolumn{2}{|c|}{ bed load } \\
\hline & $\mathrm{t} \cdot \mathrm{y}^{-1}$ & $\mathrm{~m}^{3} \cdot \mathrm{y}^{-1}$ & $t \cdot y^{-1}$ & $\mathrm{~m}^{3} \cdot \mathrm{y}^{-1}$ & $t \cdot y^{-1}$ & $\mathrm{~m}^{3} \cdot \mathrm{y}^{-1}$ \\
\hline Sounding reservoir's basin & - & 3638.7 & - & - & - & - \\
\hline $\begin{array}{l}\text { Denudation index of Brański (2) together with bed load } \\
\text { acc. to Wilhelm's formula (4) }\end{array}$ & 6960.9 & 8532.1 & 5313.5 & 7590.7 & 1647.4 & 941.4 \\
\hline $\begin{array}{l}\text { Denudation index of Brański (2) together with bed load } \\
\text { taken as } 35 \% \text { of suspension from eq. (2) after Skibiński }\end{array}$ & 7554.1 & 8871.0 & 5313.5 & 7590.7 & 2240.6 & 1280.3 \\
\hline $\begin{array}{l}\text { Turbidity index of Brański (3) together with bed load acc. } \\
\text { to Wilhelm's formula (4) }\end{array}$ & 5027.9 & 5770.7 & 3380.5 & 4829.3 & 1647.4 & 941.4 \\
\hline $\begin{array}{l}\text { Turbidity index of Brański (3) together with bed load taken } \\
\text { as } 35 \% \text { of suspension from eq. (2) after Skibiński }\end{array}$ & 5621.1 & 6109.6 & 3380.5 & 4829.3 & 2240.6 & 1280.3 \\
\hline
\end{tabular}




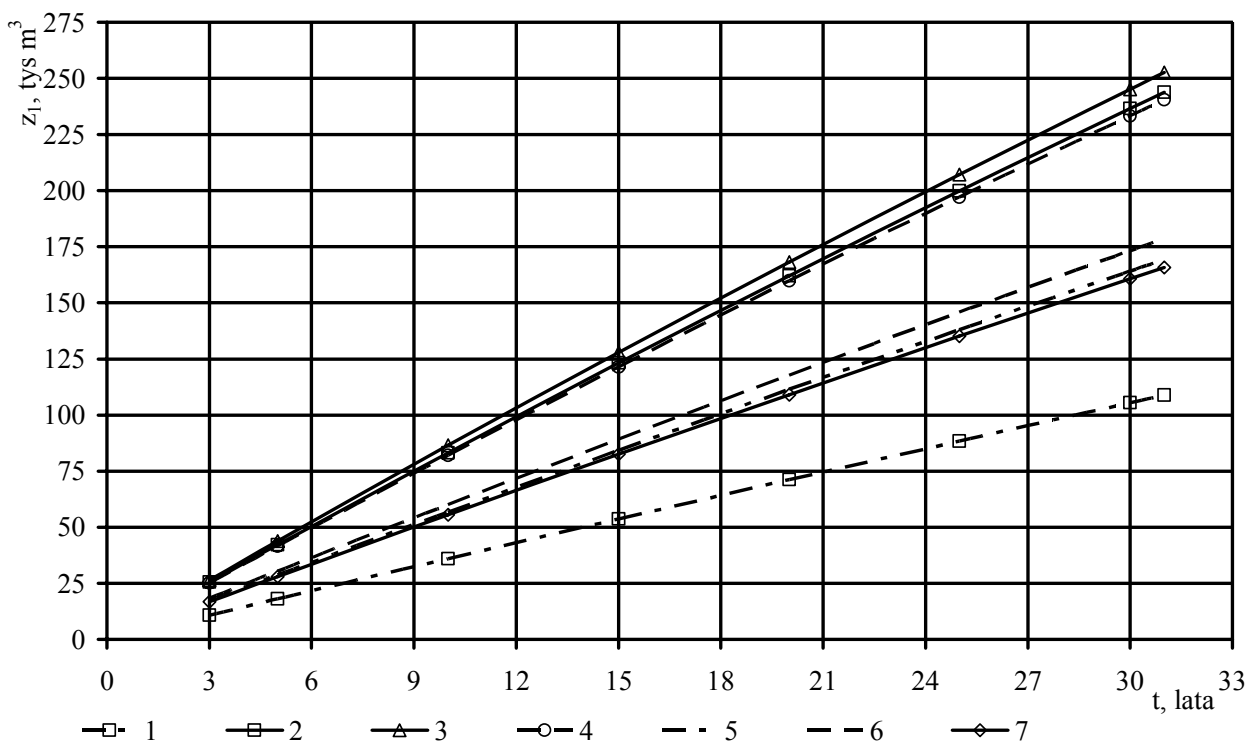

Fig. 6. The course of siltation of Cedzyna reservoir for adopted calculation methods during 31 years of exploitation; explanation of curves as in table 6

\section{CONCLUSIONS}

Based on measurements and analyses of capacity and on calculations of loads delivered to Cedzyna reservoir one may presents the following conclusions:

1. The loss of reservoir capacity during 31 years of exploitation calculated from sounding the reservoir's basin was 112.8 thousand $\mathrm{m}^{3}$.

2. Analysis of the sounding records showed that an average distance between sounded points could have been up to $16 \mathrm{~m}$.

3. Mean annual mass of denudation products in the Cedzyna reservoir catchment basin estimated with the Reniger-Dębski method was 6-9 times greater (depending on applied method) than the load delivered to reservoir.

4. Life span of reservoir calculated from sounding data was 685 years. It was an approximate period of its possible use because of only 31 years of its exploitation.

\section{REFERENCES}

1. BARTNIK W., 1997. Warunki kształtujące charakter ruchu materiału dennego w rzekach i potokach górskich. (Factors affecting the movement of bottom material in mountain streams and rivers). Monogr. Kom. Gosp. Wod. PAN 13: 47-68. 
2. BRAŃSKI J., 1968. Charakterystyka transportu rumowiska unoszonego w rzekach polskich. (Characteristics of suspended load in Polish rivers). Gosp. Wod. nr 11: 415-418.

3. BRAŃSKI J., 1975. Ocena denudacji dorzecza Wisły na podstawie wyników pomiarów rumowiska unoszonego. (Evaluation of denudation of the Vistula catchment basin based on measurements of suspended load). Prace IMGW nr 6: 6-58.

4. BRAŃSKI J., DĄBKOWSKI Sz.L., 1976. Uwagi o prognozowaniu zamulenia zbiorników wodnych na rzekach nizinnych. (Notes on forecasting the siltation of water reservoirs on lowland rivers). Arch. Hydrotech. t. 23 z. 3: 375-392.

5. CHAIŃSKI J., 2000. Instrukcja eksploatacji zbiornika wodnego Cedzyna. (Instruction of exploitation of Cedzyna reservoir). Kielce.

6. DĄBKOWSKi Sz.L., 1974. Niektóre zagadnienia zamulania zbiorników wodnych na przykładzie zbiornika Włocławek na Wiśle. (Some problems of siltation of water reservoirs - a case study of Włocławek reservoir on the Vistula). Arch. Hydrotech. z. 1 t. 21: 12-29.

7. DĄBKOWSKi Sz.L., 1989. Analiza oporów ruchu wody i kształtowania się średnich głębokości strumieni w korytach rzek o dnie piaszczystym. (An analysis of water resistance and formation of mean depths in channels of sandy bottom rivers). Warszawa, Wydaw. SGGW-AR.

8. DĘBSKI K., 1959. Próba oszacowania denudacji na obszarze Polski. (An attempt to assess denudation in Poland). Pr. St. Komit. Gosp. Wod. t. 2 cz. 1.

9. GONČAROV V.N., 1962. Dinamika ruslovych potokov. Leningrad: 323-326.

10. KondRACKI J., 2000. Geografia regionalna Polski. (Regional geography of Poland). Warszawa, PWN.

11. ŁAJCZAK A., 1995. Studium nad zamulaniem wybranych zbiorników zaporowych w dorzeczu Wisły. (A study on siltation of selected dam reservoirs in the Vistula catchment basin). Monografie Komitetu Gospodarki Wodnej PAN z. 8.

12. MiCHALEC B., 2001. Ocena stopnia zamulania małych zbiorników karpackich na tle natężenia transportu rumowiska unoszonego i wleczonego. (Evaluation of siltation of small Carpathian reservoirs against the transport of suspended and bed load - PhD thesis). Rozpr. dokt. Kraków, AR.

13. MroczeK J., RAtOMSKi J., WACŁAWSKi M., 1997. Sedymentacja rumowiska w zbiorniku Tresna. (Sedimentation in Tresna reservoir). Monogr. Komit. Gosp. Wod. PAN 13. Warszawa: 31-45.

14. Reniger A., 1959. Zagadnienie erozji gleb w Polsce. (Soil erosion in Poland). Pr. Stud. Komit. Gosp. Wod. PAN z. 2 cz. 1.

15. SIDEŁ G., 2005: Hydrologia obszaru województwa świętokrzyskiego. (Hydrology of Świętokrzyskie Voivodship). http://fotowizjer.republika.pl/hydrologia.htm

16. SKIBIŃSKI J., 1976. Próba ilościowej oceny intensywności transportu rumowiska wleczonego w rzekach środkowej Polski. (An attempt of quantitative evaluation of bed load in rivers of middle Poland). Zesz. Nauk. SGGW-AR Rozpr. Nauk. 74.

17. TRAMPLER T., 1990. Regionalizacja przyrodniczo-leśna na podstawach ekologicznofizjograficznych. (Natural and forest regionalisation based on ecologic and physiographic features) Warszawa, PWRiL.

18. WIŚNIEWSKI B., 1969. Zamulanie zbiorników wodnych w Polsce oraz próba jego prognozy na podstawie intensywności denudacji. (Siltation of water reservoirs in Poland and an attempt of its forecasting based on the intensity of denudation) Arch. Hydrotech. z. 4 t. 16: 481-503. 


\section{STRESZCZENIE}

\section{Ocena i prognoza zamulania zbiornika wodnego Cedzyna}

Słowa kluczowe: pojemność zbiornika, prognoza zamulania, zamulanie, zbiornik wodny

W pracy przedstawiono zmiany pojemności zbiornika wodnego Cedzyna w okresie jego eksploatacji od 1972 do 2003 r. Podstawą analiz były przekroje poprzeczne czaszy zbiornika z 1967 r., czyli z okresu przed napełnieniem zbiornika, oraz wykonane w 2003 r. za pomoca echosondy Ceeducer. Prognoza zamulenia zbiornika została przygotowana $\mathrm{z}$ wykorzystaniem metod empirycznych. Stwierdzono zmniejszenie pojemności pierwotnej zbiornika o 112,8 tys. $\mathrm{m}^{3} \mathrm{w}$ okresie 31 lat jego eksploatacji, a jego żywotność określono na 685 lat. Dodatkowo, przeprowadzono analizę błędów w obliczeniu pola przekroju, gdy zmianie ulega liczba punktów sondowania. W tym przypadku stwierdzono, że w pomiarze echosondą Ceeducer nie ma potrzeby notowania współrzędnych i głębokości zbyt dużej liczby punktów, a dla zbiornika Cedzyna wystarczające jest, by odległość między punktami pomiarowymi wyniosła do $16 \mathrm{~m}$.

Reviewers:

Prof. Kazimierz Banasik

Prof. Wojciech Bartnik 